\title{
Intracranial Pressure is a Better Predictor of Mortality than Cerebral Perfusion Pressure
}

\author{
Ronald J Markert, Jonathan M Saxe, Cathryn L Chadwick
}

\begin{abstract}
Objective: To evaluate whether elevated intracranial pressure (ICP) or depressed cerebral perfusion pressure (CPP) is a better predictor of intracranial compartment syndrome and long-term functional outcomes in blunt traumatic brain injury.

Methods: This was a retrospective evaluation of data collected on 203 patients with blunt traumatic brain injury who were admitted to Miami Valley Hospital, a Level I trauma center, over a 2 years period, whose initial hospital management required an intracranial pressure monitor. Serial measurements of ICP and CPP were recorded during the patients' hospital stay. These patients were then evaluated at 3,6,12 and 24 months post-injury to assess their outcome based on functional status, as defined by death vegetative state, severe disability, moderate disability and good recovery.
\end{abstract}

Results: Utilizing an ICP cut-off value of 25 or greater and a CPP value of less than 60 at any point during the patients' hospital course, ICP elevation consistently correlated with a higher percentage of deaths and persistent vegetative state than a depression in CPP value. Outcomes as measured by severe or moderate disability where similar in both groups. However, neither measure approached statistical significance.

Conclusion: ICP appears to be a better predictor of intracranial compartment syndrome and extent of brain injury, predicting better than CPP values, the outcome of death or persistent vegetative state. This may help to predict prognosis, change management strategies and guide discussions with family, especially in the early phase of injury.

Keywords: Traumatic brain injury (TBI), Cerebral perfusion pressure (CPP), Intracranial pressure (ICP).

How to cite this Article: Markert RJ, Saxe JM, Chadwick CL. Intracranial Pressure is a Better Predictor of Mortality than Cerebral Perfusion Pressure. Panam J Trauma Critical Care Emerg Surg 2012;1(1):15-19.

Source of support: Nil

Conflict of interest: None declared

\section{RESUMEN}

Objetivos: Evaluar si la elevación de la presión intracraneal (PIC) o la disminución de la presión de perfusión cerebral (PPC) es un mejor predictor de un síndrome compartimental intracraneanio y los resultados funcionales a largo plazo en el trauma craneoencefálico contuso.

Métodos: Este fue un estudio retrospectivo de los datos recolectados de 203 pacientes con trauma craneoencefálico contuso que fueron admitidos al Hospital del Valle en Miami, un centro de trauma nivel I, a lo largo de un período de 2 años, cuyo manejo hospitalario inicial requirió un monitor de presión intracraneal. Determinaciones seriadas de la PIC y la PPC se registraron durante la estancia hospitalaria de los pacientes. Luego estos pacientes fueron evaluados a los 3,6,12 y 24 meses después de la lesión para evaluar los resultados basándose en el estado funcional, tal como se define por la estado de muerte vegetativo, discapacidad grave, discapacidad moderada y buena recuperación.

Resultados: Utilizando un valor de corte de ICP de 25 o mayor y un valor CPP menor de 60 en cualquier momento durante la estancia hospitalaria del paciente, la elevación de la PIC siempre correlaciono con un mayor porcentaje de muertes y el estado vegetativo persistente que en cuanto a una disminicion en el valor de la PPC. Los resultados, medidos como discapacidad grave o moderada, fueron similar en ambos grupos. Sin embargo, ninguna de las medidas se acercó a la significación estadística.

Conclusión: La PIC parece ser un mejor predictor para el síndrome de compartimiento intracraneal y extensión de la lesión cerebral, prediciendo mejor que los valores del PPC, el resultado de la muerte el estado vegetativo persistente. Esto puede ayudar a predecir el pronóstico, cambiar estrategias de manejo y guiar las discusiones con la familia, especialmente en la fase temprana de la lesión.

Palabras clave: Presión intracraneal (PIC), Presión de perfusión cerebral (PPC), Síndrome de compartimiento intracraneano, Síndrome hipertensión intracraneana, Trauma craneoencefalico (TEC).

\section{INTRODUCTION}

One of the most controversial areas of traumatic brain injury critical care is the management of cerebral perfusion pressure (CPP). CPP is the difference between the mean arterial pressure (MAP) and the intracranial pressure (ICP). ${ }^{1}$ When pressure autoregulation is impaired and when CPP is below the lower limit of pressure autoregulation, cerebral blood flow (CBF) is dependent on CPP. ${ }^{2-4}$ It is important to emphasize that the controversial issue is not hypotension because overwhelming evidence from numerous clinical studies shows that hypotension has adverse consequences for the patient with TBI. ${ }^{2-4}$ Rather, the key controversial issues are what is the minimum level of CPP that is adequate for a brain-injured patient. Does increasing CPP beyond the minimum level, which provides adequate perfusion of the brain, have an additional beneficial therapeutic effect? Does increased levels of CPP provide any advantage over current management? ${ }^{5}$

In the United States, there has been a push toward protocol driven care. ${ }^{6}$ Our center is no different with a CPP protocol used in all patients with an intracranial pressure monitor (ICP). At times, however, in an attempt to provide adequate CPP levels mean arterial blood pressure were being 
driven to abnormal levels. We hypothesized that increasing mean arterial pressure beyond normal values does not in fact increase CBF but may in fact be detrimental. The CPP is also a calculated number developed from two independent variables MAP and ICP. We felt that in patients with high ICP pushing CPP through increasing MAP would have at least no effect and may instead be deleterious. To answer this question we embarked on a study to determine if CPP or ICP is a better predictor of death.

\section{METHODS}

We performed a retrospective analysis of prospectively compiled traumatic brain injury database at a single level one-trauma center. Institutional review board permission was obtained prior to data collection. Data collected included demographic data, which included: Age, gender and race. Prehospital data including glasgow coma scale (GCS) EMS, Paralytic drug usage by EMS was collected. Initial resuscitation (ER) data collected included GCS ER, paralytic drug usage ER, lowest $\mathrm{SaO}_{2}$, pupillary response, systolic blood pressure lowest ER. Intensive care unit (ICU) data collected comprised; ICP $>20$ hours, ICP $>25$ hours, Mannitol high 10 ICU days, length of stay (los) ICU, length of stay (LOS) total, mortality, injury severity score (ISS), abbreviated injury score head (AIS), outcome 3 months, outcome 6 months, outcome 12 months, outcome 24 months, hours until death, death within 48 hours, ventilator days, pneumonia, red blood cell transfusion, craniotomy, hours CPP $<60$, basal cisterns midbrain, midline shift foramen, SAH basal cisterns, Intraventricular hemorrhage, multiple Parenchymal lesions, ICP > 25. Data was analysis by Chi-square and students t-test where appropriate.

\section{RESULTS}

The database included 203 patients who were available for analysis. The average age of the patients in this study was 45-year-old. The patients, in this study, where predominately male $(76 \%)$ and chiefly Caucasian $(87.7 \%)$. The average glasgow coma scale (GCS) at initial resuscitation was five with an average injury severity score (ISS) of 24 . The abbreviated injury severity (AIS) for neurotrauma was four indicating traumatic brain injury was the most important injury in most of the patients in this study. The systolic blood pressure (SBP) averaged 112 systolic. Systolic blood pressure in this range would indicative adequate perfusion at the time of assessment (Table 1).

Intracranial pressure (ICP) greater than $25 \mathrm{~mm} \mathrm{Hg}$ is generally accepted as representing the pressure which when reached requires some type of intervention. In patients who were found to have an ICP of greater than 25 on initial bolt

\begin{tabular}{llc}
\multicolumn{3}{l}{ Table 1: Patient demographics and scores with blunt traumatic } \\
brain injury
\end{tabular}

placement the mortality rate was $29 \%$. In patients who had ICP pressures of 25 or greater for up to 10 hours, the mortality was $21 \%$. For patients with ICP above 25 for 11 to 50 hours the mortality rate was $50 \%$. When ICP was elevated greater than 25 for more than 50 hours the mortality rate was $74 \%$. (Table 2 ).

For cerebral perfusion pressure (CPP), there is no accepted length of time for study. This analysis we look at total time using time below CCP of 60 for 14 hours as our cut off. Comparisons where made of those patients who had a total time of CCP less than 60 less than 14 hours vs greater than 14 hours total time. This was done to separate early deaths from those who a more prolonged course. CPP of less than 60 was accurate in predicting death in the early $30 \%$ of the time. When CPP was less than 60 for greater than 14 hours the prediction of mortality was only $41 \%$ (Table 3 )

Statistical analysis failed to show any significance however the trends would indicate that ICP is a better predictor of mortality than CPP (Tables 4 and 5). 
Intracranial Pressure is a Better Predictor of Mortality than Cerebral Perfusion Pressure

\begin{tabular}{|c|c|c|c|c|c|c|c|c|c|}
\hline & & & \multirow{2}{*}{\multicolumn{6}{|c|}{ Outcome 3 months }} & \multirow{3}{*}{ Total } \\
\hline & & & & & & & & & \\
\hline & & & Dead & Vegetative & $\begin{array}{l}\text { Severe } \\
\text { disability }\end{array}$ & $\begin{array}{l}\text { Moderate } \\
\text { disability }\end{array}$ & $\begin{array}{l}\text { Good } \\
\text { recovery }\end{array}$ & $\begin{array}{l}\text { Lost to } \\
\text { follow-up }\end{array}$ & \\
\hline \multirow[t]{8}{*}{ ICP $>25$ four category } & 0 hours & Count & 24 & & 4 & 11 & 19 & 23 & 81 \\
\hline & & $\begin{array}{l}\% \text { within } \\
\text { ICP > } 25 \text { four } \\
\text { category }\end{array}$ & $29.60 \%$ & & $4.90 \%$ & $13.60 \%$ & $23.50 \%$ & $28.40 \%$ & $100 \%$ \\
\hline & 1 to 10 hours & Count & 11 & 2 & 8 & 20 & 7 & 5 & 53 \\
\hline & & $\begin{array}{l}\% \text { within } \\
\text { ICP }>25 \text { four } \\
\text { category }\end{array}$ & $20.80 \%$ & $3.80 \%$ & $15.10 \%$ & $37.70 \%$ & $13.20 \%$ & $9.40 \%$ & $100 \%$ \\
\hline & 11 to 50 hours & Count & 23 & & 5 & 6 & 3 & 9 & 46 \\
\hline & & $\begin{array}{l}\% \text { within } \\
\text { ICP }>25 \text { four } \\
\text { category }\end{array}$ & $50 \%$ & & $10.90 \%$ & $13.00 \%$ & $6.50 \%$ & $19.60 \%$ & $100 \%$ \\
\hline & More than 50 hours & Count & 17 & 2 & 1 & 1 & 2 & & 23 \\
\hline & & $\begin{array}{l}\% \text { within } \\
\text { ICP > } 25 \text { four } \\
\text { category }\end{array}$ & $73.90 \%$ & $8.70 \%$ & $4.30 \%$ & $4.30 \%$ & $8.70 \%$ & & $100 \%$ \\
\hline \multirow[t]{2}{*}{ Total } & & Count & 75 & 4 & 18 & 38 & 31 & 37 & 203 \\
\hline & & $\begin{array}{l}\% \text { within } \\
\text { ICP > } 25 \text { four } \\
\text { category }\end{array}$ & $36.90 \%$ & $2 \%$ & $8.90 \%$ & $18.70 \%$ & $15.30 \%$ & $18.20 \%$ & $100 \%$ \\
\hline
\end{tabular}

\begin{tabular}{|c|c|c|c|c|c|}
\hline \multicolumn{6}{|c|}{ Table 3: CPP group } \\
\hline & & & Dead & Vegetative & $\begin{array}{l}\text { Severe } \\
\text { disability }\end{array}$ \\
\hline \multirow[t]{4}{*}{ CPP group } & CPP $<60$ for $<14$ hours & Count & 22 & 2 & 10 \\
\hline & & $\%$ within CPP group & $30.10 \%$ & $2.70 \%$ & $13.70 \%$ \\
\hline & $\mathrm{CPP}<60$ for 14 or $>$ hours & Count & 29 & 1 & 7 \\
\hline & & $\%$ within CPP group & $40.80 \%$ & $1.40 \%$ & $9.90 \%$ \\
\hline \multirow[t]{2}{*}{ Total } & & Count & 51 & 3 & 17 \\
\hline & & $\%$ within CPP group & $35.40 \%$ & $2.10 \%$ & $11.80 \%$ \\
\hline
\end{tabular}

Table 4: ICP $>25$

\begin{tabular}{|c|c|c|c|c|c|}
\hline & & & \multicolumn{2}{|c|}{3 month outcome-2 category } & \multirow[b]{2}{*}{ Total } \\
\hline & & & Dead & Alive & \\
\hline \multirow{4}{*}{$\begin{array}{l}\text { ICP }>25 \text { two } \\
\text { category }\end{array}$} & 0 hours & Count & 24 & 34 & 58 \\
\hline & & $\%$ within ICP $>25$ two category & $41.40 \%$ & $58.60 \%$ & $100.00 \%$ \\
\hline & 1 or more hours & Count & 51 & 57 & 108 \\
\hline & & $\%$ within ICP > 25 two category & $47.20 \%$ & $52.80 \%$ & $100.00 \%$ \\
\hline \multirow[t]{2}{*}{ Total } & & Count & 75 & 91 & 166 \\
\hline & & $\%$ within ICP > 25 two category & $45.20 \%$ & $54.80 \%$ & $100.00 \%$ \\
\hline \multicolumn{6}{|c|}{ Chi-square tests } \\
\hline \multicolumn{6}{|c|}{ Pearson Chi-square value 0.520} \\
\hline
\end{tabular}




\begin{tabular}{|c|c|c|c|c|c|}
\hline \multicolumn{6}{|c|}{ Table 5: CPP $<60$} \\
\hline & & & Dead & Alive & Total \\
\hline \multirow[t]{4}{*}{ CPP group } & $\mathrm{CPP}<60$ for $<14$ hours & Count & 22 & 39 & 61 \\
\hline & & $\%$ within CPP group & $36.10 \%$ & $63.90 \%$ & $100.00 \%$ \\
\hline & $\mathrm{CPP}<60$ for 14 or $>$ hours & Count & 29 & 33 & 62 \\
\hline & & $\%$ within CPP group & $46.80 \%$ & $53.20 \%$ & $100.00 \%$ \\
\hline \multirow[t]{2}{*}{ Total } & & Count & 51 & 72 & 123 \\
\hline & & $\%$ within CPP group & $41.50 \%$ & $58.50 \%$ & $100.00 \%$ \\
\hline \multicolumn{6}{|c|}{ Chi-square tests } \\
\hline
\end{tabular}

\section{DISCUSSION}

The pathophysiology of traumatic brain injury remains controversial. In an attempt to improve outcomes many techniques have been attempted. One approach is based on physiologic concept called the vasodilatory cascade. According to this hypothesis, a reduction in CPP-either a decrease in arterial blood pressure, an increase in ICP, or both-stimulates the cerebral vessels to dilate in an attempt to maintain $\mathrm{CBF}^{5-9}$ This is the normal pressure auto regulatory response to a decrease in CPP. The increase in cerebral blood volume that accompanies the vasodilation further reduces CPP by increasing ICP. This cycle may lead to ever reducing CPP. ${ }^{9-11}$ An increase in arterial blood pressure under this circumstance has been observed to break the cycle and reduce ICP. A detailed description of this approach is given in a recent report of a clinical. In this series of 158 patients admitted with glasgow coma scale score less than 7, mortality was only $29 \%$, and $59 \%$ achieved a good recovery or moderate diaability at 6 months. ${ }^{2}$ There was believed to be sufficient value in this practice that it was included in the 1996 Head Injury Guidelines. There has been wide acceptance of this approach. In fact our centers protocol has been driven by this thesis.

Another recent approach, called the Lund therapy, emphasizes reduction in microvascular pressures to minimize edema formation in the brain . The goals of this approach are to preserve a normal colloid osmotic pressure (infusion of albumin and erythrocytes), to reduce capillary hydrostatic pressures by reducing systemic blood pressures (metoprolol and clonidine), and to reduce cerebral blood volume by vasoconstricting precapillary resistance vessels. ${ }^{16}$

Another more recent approach has been to treat traumatic brain injury as compartment syndrome. This has lead to liberal use of ventriculostomy, as well as early decompressive craniotomy to control ICP. Fluid and pressure agents as adjucts to maintain MAP to appropriate levels and ICP by decompression of either fluid or restrictive space. ${ }^{13-15}$
The approach in this study emphasized the use of fluids as well as pressure agents (neosynephrine) to maximize CPP. Management of ICP was limited to medical therapy including manitol, sedation and phenobarbital coma. Frequently this approach when ICP is greater than $25 \mathrm{~mm} \mathrm{Hg}$ leads to MAP of 90 to $100 \mathrm{~mm} \mathrm{Hg}$ in order to maintain an CPP of 60. MAP in these ranges may be counter productive. Although our data does not demonstrate any deleterious effects there was no improvement either. ${ }^{12}$

There are several shortcomings in his study. This study is a retrospective study and inherently is biased. Despite protocol driven care driving MAP to artificially high values may have been counter productive and exacerbated penumbral areas of injury. ICP is part of the CPP calculation making ICP an contributing factor in analysis of effects of CPP. Finally, although we saw trends indicating ICP is a better predictor of mortality than CPP.

Despite these shortcoming, the data presented in this study would support the view that severe TBI produces a compartment syndrome. Efforts to drive CPP in order to break the cycle of vasoconstriction are not supported by our data. We would recommend all endeavors to decrease ICP including ventriculostomy and decompressive crainiotomy should be utilized while maintaining normal MAP values.

\section{REFERENCES}

1. Bullock RM, Chesnut R, Clifton GL, Ghajar J, Marion DW, Narayan RK, Newell DW, Pitts LH, Rosner MJ, Walters BC, Wilberger JE. Management and prognosis of severe traumatic brain injury, part 1: Guidelines for the management of severe traumatic brain injury. J Neurotrauma 2000;17:451-553.

2. Rosner MJ, Rosner SD, Johnson AH. Cerebral perfusion pressure: Management protocol and clinical results. J Neurosurg 1995;83:949-62.

3. Brain Trauma Foundation, American Association of Neurological Surgeons, Joint Section on Neurotrauma and Critical Care: Guidelines for the management of severe head injury. J Neurotrauma 1996;13:641-734. 
4. Eker C, Asgeirsson B, Grande PO, Schalen W, Nordstrom CH. Improved outcome after severe head injury with a new therapy based on principles for brain volume regulation and preserved microcirculation. Crit Care Med 1998;26:1881-86.

5. Grande PO, Asgeirsson B, Nordstrom CH: Physiologic principles for volume regulation of a tissue enclosed in a rigid shell with application to the injured brain. J Trauma 1997; 42:S23-31.

6. Miller JD, Piper IR, Dearden NM. Management of intracranial hypertension in head injury: Matching treatment with cause. Acta Neurochir Suppl (Wien) 1993;57:152-59.

7. Paulson OB, Strandgaard S, Edvinsson L. Cerebral autoregulation. Cerebrovasc Brain Metab Rev 1990;2:161-92.

8. Strebel S, Lam AM, Matta BF, Newell DW. Impaired cerebral autoregulation after mild brain injury. Surg Neurol 1997; 47:12831.

9. Kiening KL, Hartl R, Unterberg AW, Schneider GH, Bardt T, Lanksch WR: Brain tissue pO2-monitoring in comatose patients: Implications for therapy. Neurol Res 1997;19:233-40.

10. Bruzzone P, Dionigi R, Bellinzona G, Imberti R, Stochetti N. Effects of cerebral perfusion pressure on brain tissue pO2 in patients with a severe head injury. Acta Neurochir Suppl (Wien) 1998;71:111-13.

11. Cruz J, Jaggi JL, Hoffstad OJ. Cerebral blood flow, vascular resistance, and oxygen metabolism in acute brain trauma: Redefining the role of cerebral perfusion pressure? Crit Care Med 1995;23:1412-17.

12. Chan KH, Miller JD, Dearden NM, Andrews PJ, Midgley S. The effect of changes in cerebral perfusion pressure upon middle cerebral artery blood flow velocity and jugular bulb venous oxygen saturation after severe brain injury. J Neurosurg 1992; 77:55-61
13. Marmarou A, Anderson RL, Ward JD, Choi SC, Young HF, Eisenberg HM, Foulkes MA, Marshall LF, Jane HA. Impact of ICP instability and hypotension on outcome in patients with severe head injury. J Neurosurg 1991;75:S59-64.

14. Struchen MA, Hannay HJ, Contant CF, Robertson CS. The relation between acute physiological variables and outcome on the GOS and DRS following severe traumatic brain injury. J Neurotrauma 2001;18:115-25.

15. Downard C, Hulka F, Mullins RJ, Platt J, Chesnut R, Quint P, Mann NC. Relation of cerebral perfusion pressure and survival in pediatric brain-injured patients. J Trauma 2000;49:654-58.

16. Robertson CS, Valadka AB, Hannay HJ, Contant CF Jr, Gopinath SP, Cormio M, Uzura M, Grossman RG: Prevention of secondary insults after severe head injury. Crit Care Med 1999;27:2086-95.

\section{ABOUT THE AUTHORS}

\section{Ronald J Markert}

Professor, Department of Medicine, Surgery and Orthopedics, WSU School of Medicine, Dayton, Ohio, USA

\section{Jonathan M Saxe (Corresponding Author)}

Professor, Department of Surgery, WSU Medical Center, Dayton Ohio, USA, e-mail: jmsaxe@mvh.org

\section{Cathryn L Chadwick}

Former Fellow, Department of Surgery, WSU School of Medicine Dayton, Ohio, USA 